University of Nebraska - Lincoln

DigitalCommons@University of Nebraska - Lincoln

3-1-2005

\title{
Registration of Common Bacterial Blight Resistant Pinto Bean Germplasm Line ABCP-8
}

N. Mutlu

University of Nebraska-Lincoln, nmutlu2@unl.edu

P.N. Miklas

J. R. Steadman

University of Nebraska-Lincoln, jsteadman1@unl.edu

A. K. Vidaver

University of Nebraska-Lincoln, avidaver1@unl.edu

Dale T. Lindgren

University of Nebraska-Lincoln, dlindgren1@unl.edu

See next page for additional authors

Follow this and additional works at: https://digitalcommons.unl.edu/plantpathpapers

Part of the Plant Pathology Commons

Mutlu, N.; Miklas, P.N.; Steadman, J. R.; Vidaver, A. K.; Lindgren, Dale T.; Reiser, J.; Coyne, D.P.; and PatorCorrales, M. A., "Registration of Common Bacterial Blight Resistant Pinto Bean Germplasm Line ABCP-8" (2005). Papers in Plant Pathology. 61.

https://digitalcommons.unl.edu/plantpathpapers/61

This Article is brought to you for free and open access by the Plant Pathology Department at DigitalCommons@University of Nebraska - Lincoln. It has been accepted for inclusion in Papers in Plant Pathology by an authorized administrator of DigitalCommons@University of Nebraska - Lincoln. 


\section{Authors}

N. Mutlu, P.N. Miklas, J. R. Steadman, A. K. Vidaver, Dale T. Lindgren, J. Reiser, D.P. Coyne, and M. A. PatorCorrales 


\section{Registration of Common Bacterial Blight Resistant Pinto Bean Germplasm Line ABCP-8}

Pinto bean (Phaseolus vulgaris L.) germplasm line ABCP8 (Reg. no. GP- 237, PI 635118) was developed by the University of Nebraska Agricultural Research Division in cooperation with USDA-ARS and released in 2004. This line was bred specifically for enhanced resistance to common bacterial blight [caused by Xanthomonas campestris pv. phaseoli (Smith) Dye]. Pinto and other dry bean market classes (dark red kidney, great northern, navy, etc.) grown in the U.S.A. east of the continental divide are often attacked by common bacterial blight, a seed-transmitted disease that causes up to $40 \%$ yield loss in susceptible cultivars as well as reduction of seed quality through discoloration of infected seed. Development of cultivars with genetic resistance combined from different sources is the most cost effective method to control common bacterial blight.

ABCP-8 is the first pinto bean to combine the XAN 159 and great northern Montana No. 5 (Miklas et al., 2003) sources of common bacterial blight resistance. Combined resistance was confirmed by the presence of previously developed SCAR markers SU91 (Pedraza et al., 1997) and SAP6 (Miklas et al., 2003) tightly linked with quantitative trait loci (QTL) from XAN 159 and Montana No. 5, respectively. In addition to common bacterial blight resistance, ABCP- 8 possesses the $U r-3$ gene for resistance to rust [caused by Uromyces appendiculatus (Pers.:Pers.) Unger] as indicated by resistance to rust Races 41, 53, and 108, and the $b c-1^{2}$ gene for resistance to Bean common mosaic virus (BCMV) and Bean common mosaic necrosis virus (BCMNV) Pathogroups 1,2,3, and 5 and partial resistance to NL-3 strain of Pathogroup 6 of BCMNV.

ABCP-8 pinto is a $\mathrm{BC}_{5} \mathrm{~F}_{3: 6}$ line obtained from five backcrosses ('Chase'*5/XAN 159) between the donor parent XAN 159 and recurrent parent Chase pinto. Seeds of XAN 159 are

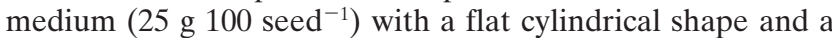
gray-speckled fine-dotting seed coat pattern. XAN 159 was developed for resistance to common bacterial blight at the Centro Internacional Agricultura Tropical (CIAT) by selection from the interspecific cross 'UI 114' pinto/PI 319441//PI 319443 (P. acutifolius A. Gray)/'Masterpiece' made by Thomas and Waines (1984). XAN 159 was estimated to have up to five QTL for resistance to common bacterial blight (Eskridge and Coyne, 1996). It is susceptible to rust and BCMV. Chase was derived from a cross between a great northern breeding line, GN-WM-84-17, and a pinto breeding line, P-WM-84-45, from the University of Nebraska dry bean breeding program. Chase is resistant to rust ( $U r-3$ gene) and moderately resistant to bacterial brown spot (caused by Pseudomonas syringae pv. syringae van Hall) and common bacterial blight, and expresses moderate avoidance to white mold [caused by Sclerotinia sclerotiorum (Lib.) de Bary] due to a porous canopy, but is susceptible to BCMV (Coyne et al., 1994).

The first cross was made in the spring 1997. Only $\mathrm{BC}_{n} \mathrm{~F}_{1}$ plants resistant to common bacterial blight isolates DR-7 and EK-11 as determined by multiple-needle leaf inoculation tests in the greenhouse (Andrus, 1948) were used for successive backcrossing. In addition to common bacterial blight resistance, selection for desirable pinto seed characteristics began after $\mathrm{BC}_{3}$. Single plant selections were made from inbred $\mathrm{BC}_{5}$ lines expressing the highest common bacterial blight resistance. Field evaluation of selected $\mathrm{BC}_{5} \mathrm{~F}_{3: 5}$ lines were conducted at the West Central Research and Extension Center (North Platte) and Panhandle Research and Extension Center (Scottsbluff) in Nebraska in 2001, 2002, and 2003 and at the Washington State University Experiment Station in Othello, WA, in 2002. In addition to phenotypic selection for common bacterial blight resistance, marker-assisted selection for the SU91 and SAP6 markers was conducted in the $\mathrm{BC}_{1} \mathrm{~F}_{1}$ and $\mathrm{BC}_{2} \mathrm{~F}_{1}$.

The seed size ( $30 \mathrm{~g} 100$ seed $\left.^{-1}\right)$ for ABCP-8 across locations was less than Chase (33 g 100 seed $^{-1}$ ). The yield for ABCP-8 was 117,148 , and $129 \%$ of the yield of Chase in Nebraska (2001 and 2003) and Washington (2002), respectively. ABCP-8 matured $4 \mathrm{~d}$ later than Chase in Washington. The line exhibits an indeterminate semi-prostrate growth habit similar to Chase. ABCP-8 exhibited greater resistance to common bacterial blight (6\% infection in field and greenhouse tests) than the 
recurrent parent Chase (33\% field and $46 \%$ greenhouse) and susceptible check 'Othello' pinto (59\% field and 100\% greenhouse), and similar resistance to the donor parent XAN 159 ( $8 \%$ in field and $5 \%$ in greenhouse). Disease scores were recorded as percentage diseased plants (leaves and pods) in the field under natural infection and percentage common bacterial blight symptoms visible within the inoculated leaf area of greenhouse grown plants.

The ABCP- 8 breeding line will be useful for improving resistance to common bacterial blight in the pinto bean market class. Limited quantity of seed is available from P.N. Miklas (pmiklas@pars.ars.usda.gov). We ask that appropriate recognition of source be given when this germplasm contributes to the development of a new cultivar.

\section{N. Mutlu, P.N. Miklas, J.R. Steadman,* A.K. Vidaver, D.T. LINDGREN, J. REISER, D.P. COYNE, and M.A. Pastor-Corrales}

\section{Acknowledgments}

We acknowledge Lisa Sutton and Clay Carlson for technical help and support of the Bean/Cowpea CRSP (USAID contract No. DAN-1310-G-SS-6008-00).

\section{References}

Andrus, C.F. 1948. A method of testing beans for resistance to bacterial blights. Phytopathology 38:757-759.

Coyne, D.P., D.S. Nuland, D.T. Lindgren, and J.R. Steadman. 1994. 'Chase' pinto dry bean. HortScience 29:44-45.

Eskridge, K.M., and D.P. Coyne. 1996. Estimating and testing hypotheses about the number of genes using inbred-backcross data. J. Hered. 87:410-412.

Miklas, P.N., D.P. Coyne, K.F. Grafton, N. Mutlu, J. Reiser, D. Lindgren, and S.P. Singh. 2003. A major QTL for common bacterial blight resistance derives from the common bean great northern landrace cultivar Montana No. 5. Euphytica 131:137-146.

Pedraza, F., G. Gallego, S. Beebe, and J. Tohme. 1997. Marcadores SCAR y RAPD parala resistencia a la bacteriosis comun (CBB). p.130-134. In S.P. Singh and O. Voysest (ed.) Taller de mejoramiento de frijol para el Siglo XXI: Bases para una estrategia para America Latina. CIAT, Cali, Colombia.

Thomas, C.V., and J.G. Waines. 1984. Fertile backcross and allotetraploid plants from crosses between tepary beans and common beans. J. Hered. 75:93-98.

N. Mutlu, Univ. of Nebraska, Dep. of Biochemistry, Lincoln, NE 68588; P. Miklas, USDA-ARS, Vegetable and Forage Crop Research Unit, 24106 N. Bunn Rd., Prosser, WA 99350; J. Steadman and A. Vidaver, Univ. of Nebraska, Dep. of Plant Pathology, Lincoln, NE 68583; D. Lindgren, J. Reiser, and D.P. Coyne, Univ. of Nebraska, Dep. of Agronomy and Horticulture, Lincoln, NE 68583; M. PastorCorrales, USDA-ARS, Vegetable Laboratory, Beltsville Agricultural Research Center-West, USDA-ARS, 10300 Baltimore Avenue, Beltsville, MD 20705-2350. A contribution of the University of Nebraska, Agricultural Research Division, Lincoln, NE 68583. Journal Series no. 14628. Registration by CSSA. Accepted 31 Aug. 2004. *Corresponding author (JSTEADMAN1@unl.edu).

Published in Crop Sci. 45:806-807 (2005). 